\title{
BOOK REVIEW: INSURANCE LAW
}

\author{
Renée Holmes*
}

Duncan Webb and David Rowe (eds) Insurance Law: Practice, Policy \& Principles (The Centre for Commercial and Corporate Law Inc, Christchurch, 2004) (227 + x pages)

Insurance Law: Practice, Policy \& Principles is a collection of essays covering a broad range of topical insurance law issues. Editors Duncan Webb and David Rowe have brought together a wide range of authors consisting of practitioners, academics and a student. The diversity of authors, and of subject matter, makes this not only a useful reference book covering a wide range of issues, but also interesting and varied reading.

Insurance law is often neglected by those who do not study or practice in the area. It would easily be possible to gain a law degree under the assumption that the general rules learnt in contract law govern insurance contracts. This is not the case. As this collection illustrates, some aspects of insurance cases are solved by the application of principles that are unique to insurance contracts, and are often quite different to the principles applied to contracts in general. In addition, insurance carries its own unique policy considerations. For this reason this collection of essays covering concerns and issues unique to the contemporary practice of insurance in New Zealand is welcomed.

Differences between contract law and principles applicable only to insurance contracts is a reoccurring theme amongst the essays. For example, Paul Michalik's examination of the principles governing the formation of policies in "Formation of the Contract - Insurance Law or Contract Law? Wynne $v$ New Zealand Insurance" ends with a conclusion entitled "A Reminder to keep Insurance Law at the Forefront in Insurance Cases". ${ }^{1}$ Jon Parker concludes that insurance contracts are interpreted in a different manner than commercial contracts in "Gazelle Properties Limited $v G J$ Hulst - A Case Apart". ${ }^{2}$

* Associate Editor, Victoria University of Wellington Law Review.

1 Paul Michalik "Formation of the Contract - Insurance Law or Contract Law? Wynne v New Zealand Insurance" in Duncan Webb and David Rowe (eds) Insurance Law: Practice, Policy \& Principles (The Centre for Commercial and Corporate Law Inc, Christchurch, 2004) 139, 149.

2 Jon Parker "Gazelle Properties Limited v G J Hulst-A Case Apart?" in Webb and Rowe, above n 1, 151. 
Other essays focus more on the basic theoretical principles underlying insurance contracts. Mark Fisher examines the familiar subject of the requirement for an insurable interest. ${ }^{3}$ Neil Campbell is somewhat more original in his examination of the duty of good faith. He asserts that the duty arises only at certain points during the lifecycle of the contract and cautions against adoption of an overarching duty applying throughout. ${ }^{4}$ In "An Insurer's Right to be Subrogated to the Insured's Contractual Claims", Chris Chapman and Jo Girvan look at the familiar doctrine of subrogation, with particular emphasis on the effect of the construction of a contract and waiver of subrogation clauses on the insurer's right to be subrogated to the insured's claims. ${ }^{5}$

An especially topical essay is "Genetic Testing and Insurance: the Role of the Industry and the Welfare State" which is primarily concerned with policy and the future direction of the law. In what I personally found to be the most challenging essay in the collection Andru Isac discusses the implications of genetic testing on insurance, and possible regulatory responses for the future. ${ }^{6}$ This essay stands out among the collection for its examination of an issue that will no doubt attract increasing attention in the future.

Many of the essays offer illustrations and discussions of issues and areas which are of valuable practical application or assistance. These include an evaluation of the use of alternative dispute resolution in insurance cases, ${ }^{7}$ and an explanation of the Insurance and Savings Ombudsman scheme. ${ }^{8}$ The framework outlined by Craig Brown for Determining cover in "Determining Cover: Interpretation of Policies, Causation and Fortuity" is straightforward and contains useful references to case law in Australia and Canada as well as New Zealand. ${ }^{9}$ Other titles in the book include "Recent Developments in the Scope of the Insured's Precontractual Duty of Disclosure: Strategies for Reform", 10 "Misrepresentation and Non-disclosure", 11 "The Exercise of Contractual Discretion:

3 Mark Fisher "The Concept of Insurable Interest: Inherent Requirement or Inherent Quandary within Modern Insurance Contracts?" in Webb and Rowe, above n 1, 217.

4 Neil Campbell "A Sceptical View of Good Faith in Insurance Law" in Webb and Rowe, above n 1, 205.

5 Chris Chapman and Jo Girvan "An Insurer's Right to be Subrogated to the Insured's Contractual Claims" in Webb and Rowe, above n 1,83.

6 Andru Isac "Genetic Testing and Insurance: the Role of the Industry and the Welfare State" in Webb and Rowe, above $\mathrm{n} 1,1$.

7 Melanie Bliss and Hamish McIntosh "A Guide to ADR in Insurance" in Webb and Rowe, above n 1, 17.

8 Karen Stevens "The Insurance \& Savings Ombudsman Scheme" in Webb and Rowe, above n 1, 179.

9 Craig Brown "Determining Cover: Interpretation of Policies, Causation and Fortuity" in Webb and Rowe, above $\mathrm{n} 1,31$.

10 Les Arthur "Recent Developments in the Scope of the Insured's Precontractual Duty of Disclosure: Strategies for Reform" in Webb and Rowe, above n 1, 59.

11 D F Dugdale "Misrepresentation and Non-disclosure" in Webb and Rowe, above n 1, 107. 
The Insurer as Judge in its Own Cause", ${ }^{12}$ and "Insurance Against Knowing Conduct and Offences". ${ }^{13}$

As the majority of the essays concern fundamental principles and ongoing problems, this book should retain its relevance over time. The book is aptly named given the broad range of material covered by the thirteen essays. Indeed, the only thing that many have in common is that they all fit under the general rubric of "insurance law". The collection is not designed to be a comprehensive review of the law, it appears the essays have been chosen not in an attempt to cover certain areas or to complement each other, but rather because each essay stands alone and presents a current issue of practical relevance. For this reason there has been no attempt to organise the essays under chapter headings, which is understandable given the vast array of issues covered.

Given this diversity of subject matter, it is unfortunate that the foreword is so brief, and that there is no introduction by the editors. This would have been useful in tying together such a broad range of essays, and would have made the collection more comprehensive overall. As it is, the reader is left to guess at the impetus for the book and the subsequent selection of essays. Nevertheless, each of the essays is capable of standing alone and major overlaps in subject matter have been avoided.

In some cases, the essays in this book will not present anything new to those who work in the insurance law area but will be useful for those seeking to grasp fundamentals of insurance law practice. In others, the essays examine and question principles and policies in a more in-depth fashion and offer novel suggestions. That is why this book will be relevant to a broad audience on differing levels, and will be a valuable tool for practitioners, academics and students alike.

12 Jeanette Hobbs "The Exercise of a Contractual Discretion: the Insurer as Judge in its Own Cause" in Webb and Rowe, above n 1, 117 .

13 Tim Stephens "Insurance Against Knowing Conduct and Offences" in Webb and Rowe, above n 1, 161. 